\title{
Analysis of the vegetation trends using low resolution remote sensing data in Burkina Faso (1982-1999) for the monitoring of desertification
}

\author{
Y.-C. HOUNTONDJI†t, N. SOKPON\$ and P. OZER*† \\ $\dagger$ Environmental Sciences and Management Department, University of Liège \\ †aculty of Agronomy, University of Parakou
}

(Received February 2005; in final form August 2005)

\begin{abstract}
After about two decades of dramatic rainfall deficits that started in the late 1960s, the Sahel of West Africa has experienced increasing precipitation since the early 1990s. The implementation of the United Nations Convention to Combat Desertification (UNCCD) needs the identification of areas that record declining vegetation productivity over long-time periods. In this scope, we analyse the state of the vegetation productivity using long-term time series of NOAA AVHRR NDVI data and compare it to rainfall data. For this, 128 rain gauge data (RR) were compared with the integrated NDVI during the growing period (iNDVI) values in Burkina Faso from 1982 to 1999. During the analysed period, most of the studied stations in the country were stable for the iNDVI/RR $(57.8 \%)$. However, $39.8 \%$ showed a weak to strong negative trend in the iNDVI/RR while only $2.4 \%$ showed a weak positive trend. These negative trends may reflect ongoing desertification processes in Burkina Faso and could be a starting point for the identification of hot-spots areas to determine where to take action to combat desertification.
\end{abstract}

\section{Introduction}

Since the late 1960s, the Sahel of West Africa dramatically suffered from widespread and persistent extreme rainfall deficit (Dai et al. 1998, Nicholson 1998) that continues since (L'Hôte et al. 2002) although there is a growing evidence that the drought may have ended during the 1990s (Ozer et al. 2003). In addition to this, increasing human pressure on the environment enhanced desertification processes.

Since the mid-1970s, desertification benefited of a considerable interest from scientists, politics and the public. Land degradation in arid lands is now recognized as one of the major environmental problems for the 21st century (World Bank 2002) and the Sahel of West Africa is often quoted as the most seriously affected region. Yet, desertification processes often evoke an image of advancing desert with moving dunes threatening houses, roads, oasis and fertile lands and leaving behind a barren and sterile environment (Lamprey 1975). The term desertification has been misused for a long time due to the lack of data, objective indicators and rigorous scientific studies, and because of the inexistence of a widely accepted definition (Verstraete 1986, Mainguet 1991, Thomas and Middleton 1994, Glenn et al. 1998, Nicholson et al. 1998). In addition, desertification is frequently associated to drought (Thomas 1993). For these reasons, the issue has caused considerable controversy regarding its

*Corresponding author. Email: pozer@ulg.ac.be 
nature and impacts. Many aspects of the desertification issue have been debated and challenged (Hellden 1991, Thomas 1993, Wickens 1997, Nicholson et al. 1998, Niemeijer and Mazzucato 2002) and it was shown that the advance of the Sahara desert was temporary as the southern border closely follows the fluctuations of rainfall in the Sahel belt (Tucker et al. 1991, 1994, Nicholson et al. 1998, Tucker and Nicholson 1999).

In 1994, the United Nations Convention to Combat Desertification (UNCCD) was established and ratified. The UNCCD defines desertification as 'land degradation in arid, semiarid and sub-humid areas resulting from various factors, including climate variations and human activities' where land degradation means 'reduction or loss of the biological or economic productivity and complexity of rainfed cropland, irrigated cropland, or range, pasture, forest and woodlands resulting from land uses or from a process or combination of processes, including processes arising from human activities and habitation patterns' (UN 1994).

Many authors have experienced a wide range of indicators in order to map the occurrence and severity of desertification (Mabutt 1986, Berger 1996, Mouat et al. 1997, Ozer 2000). Although many of these indicators were unsatisfactory because of their prohibitive costs and time-consuming for the process of data collection, low resolution satellite remote sensing data provide a good source of stable, reliable and long-term measurements (Prince 2002, Symeonakis and Drake 2004).

Methods have been developed to assess the vegetation net primary production (NPP) from the normalised difference vegetation index (NDVI) (Justice 1986, Prince and Justice 1991). In this paper, the NDVI is obtained from the advanced very high resolution radiometer (AVHRR) carried on the National Oceanic Atmospheric Administration (NOAA) series of meteorological satellites. The integrated NDVI during the growing period (iNDVI) data are compared with rainfall (RR) data in Burkina Faso from 1982 to 1999. Trend analysis is then applied on the obtained time series of this indicator (iNDVI/RR) in order to identify areas suffering from desertification.

\section{Study area}

Burkina Faso is a landlocked country of West Africa. The northern part of the country is situated in the Sahelo-Sudanese arid to semi-arid climatic belt (annual rainfall $<750 \mathrm{~mm}$ ) while the southern area is part of the Sudano-Guinean subhumid zone with annual rainfall above $750 \mathrm{~mm}$ (figure 1).

Burkina Faso reflects both socio-economic and environmental situations of the Sahelian countries, belongs to the poorest least developed countries of the world, with a very low human development index (0.302 in 2002) (UNDP 2004), a $3.67 \%$ population increase per year over the 1981-2002 period (FAO 2004), up to $83 \%$ of rural population (in 2002) totally dependant of their environment (FAO 2004), and a negative trend in annual forest cover change (FAO 2001).

\section{Materials and methods}

\subsection{Meteorological station data}

Monthly rainfall data were made available from an archive assembled by the Projet Alerte Précoce et Prévision des Productions Agricoles (AP3A) of the Centre Régional Agrhymet from station observations. The database includes meteorological stations through the nine countries grouped in the Inter-States Committee for 


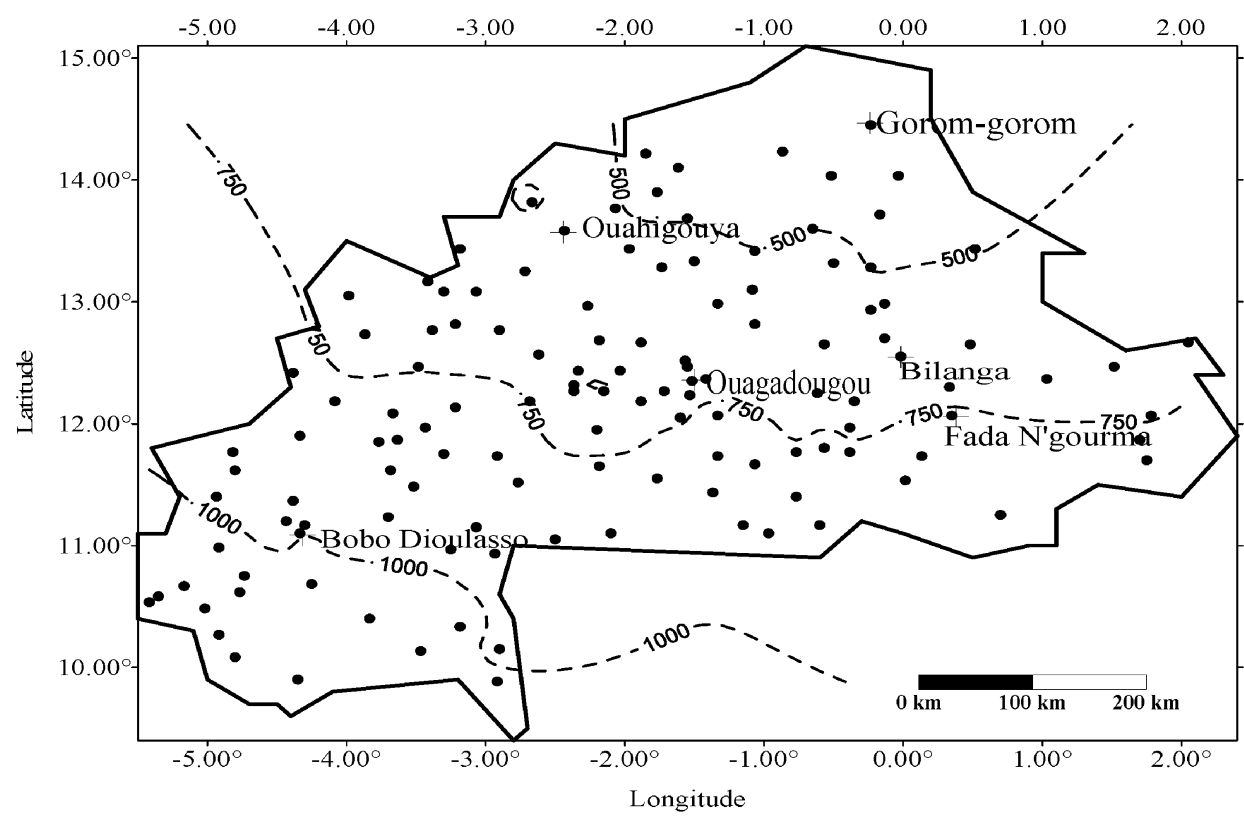

Figure 1. Geographical position of the studied stations (black dots) and bioclimatic zones (isohyets defined by kriging on average rainfall value for the 1980-2000 period).

Drought Control in the Sahel (CILSS). 128 rain gauges with complete monthly rainfall data from 1982 to 1999 were selected in Burkina Faso. The stations repartition according the bioclimatic zones is:

- Sahelian zone in the north: yearly rainfall $<500 \mathrm{~mm}$ : 12 stations.

- Sahelo-Sudanese zone in the central north: yearly rainfall between 500 and $750 \mathrm{~mm}: 54$ stations.

- Sudanese zone in the central south: yearly rainfall between 750 and $1000 \mathrm{~mm}$ : 45 stations.

- Sudano-Guinean zone in the south west: yearly rainfall $>1000 \mathrm{~mm}$ : 17 stations.

\subsection{Satellite data}

For the purpose of studying trends in vegetation greenness, we use the normalised difference vegetation index (NDVI) obtained from the National Oceanic Atmospheric Administration (NOAA) with the advanced very high resolution radiometer (AVHRR). NDVI has proved useful in numerous monitoring studies of vegetation and drought. It is calculated as the normalised difference in reflectance between the red band $(0.55 \mu \mathrm{m}-0.68 \mu \mathrm{m})$ and the near infrared band $(0.73 \mu \mathrm{m}-$ $1.1 \mu \mathrm{m})$. The NDVI is considered to be a 'greenness' index. In arid and semiarid regions, it is well correlated with parameters such as leaf area index, greenleaf, biomass, vegetation cover, etc. (Nicholson et al. 1998).

The NOAA Pathfinder dataset (James and Kalluri 1994) has been generated from NOAA AVHRR data as 10-day maximum value composites at $8 \mathrm{~km} \times 8 \mathrm{~km}$ pixel resolution. The satellite data cover Africa from 1982 to 2000 . Noise levels can be very high over many areas in Africa but are comparatively low over arid to sub-humid 
areas where cloud is limited (Chappell et al. 2001). Quality issues of the Pathfinder database are discussed by Prince and Goward (1996). Although satellite data are available from 1982 to 2000, years 1994 and 2000 were not taken into account in this paper. In 1994 there was a lack of data from September to December because of Pinatubo volcanic dust diffusion into the stratosphere (Tanaka et al. 1994). In 2000 Eklundh and Olsson (2003) detected a systematic shift in the remotely sensed data resulting from a very high shifting solar zenith angles.

128 pixels were selected when including a rain gauge station. For all pixels, the NDVI integrals (iNDVI) covering the entire growing season from June to October were computed in order to assess the annual net primary production (Diallo et al. 1991; Rasmussen 1998). This approach has been preferred to the use of rasterized rainfall data obtained from satellite estimations, because of stormy features and high spatial variation of Sahelian rainfall. Amani and Lebel (1997), exhibit a significant difference in annual rainfall score within a $10 \mathrm{~km}$ distance in Niger. This implies that the spatial rainfall variability on a small scale is more significant than on the survey level scale.

\subsection{The ratio of integrated NDVI to rainfall}

The net annual increase of biomass, or net primary production, is a measure of the production of an ecosystem. This quantity bears a direct relationship to photosynthesis and NDVI is strongly correlated with both, particularly in arid lands. Le Houérou (1984) suggests that the ratio of primary production to rainfall, NDVI/RR (rain use efficiency) is a better parameter to characterise arid and semi arid regions like the Sahel. For this research, we derived this ratio during the growing season, so that its formulation is equivalent to:

$$
\mathrm{iNDVI} / \mathrm{RR}=\text { ?XX/XX? }
$$

where RR is the monthly rainfall and NDVI is the monthly normalised difference vegetation index.

In the Sahel, the dynamic of the vegetation is strongly linked to the rainfall evolution (Hess et al. 1996, Nicholson et al. 1998, Milich and Weiss 2000a, 2000b, Foody 2003, Symeonakis and Drake 2004). In arid land regions with an annual rainfall of $200 \mathrm{~mm}$ to $1000 \mathrm{~mm}$ the iNDVI/RR ratio is regarded as a useful proxy for rain-use efficiency (Nicholson et al. 1990, Davenport and Nicholson 1993). As mentioned by previous studies in the West African Sahel (Diallo et al. 1991, Rasmussen 1998, Prince et al. 1998, Diouf and Lambin 2001, Tottrup et al. 2004), with spatially comprehensive measurements such as these, the incidence of the individual components of desertification could be detected.

\subsection{Trend analysis}

For each station, trends from 1981 through 1999 were estimated by linear regression considering the ratio iNDVI/RR as dependant variable and time (years) as independent variable. The regression slopes were recorded for each station as parameters characterizing the global trends either for the rainfall or for NDVI. Moreover, each slope was mapped in five classes indicating strong or weak positive or negative and stable trends, adapting a procedure suggested by Eklundh and Olsson (2003). The regression procedure supplies a Student $t$-test and its resulting significance $p$-level to analyse the hypothesis that the slope is equal to 0 . This $p$-level 
was used as a criterion to define the class boundaries. The trends, for the iNDVI/RR ratio, were labelled as 'strong' if the p-level exceeded 0.1 for the one-tailed $t$-test, 'weak' if the $p$-level is ranged between 0.1 and 0.3 and otherwise 'stable' if the $p$-level is up to 0.3 .

These long-term linear trends for each pixel in the iNDVI/RR ratio may be understood as a combination of a number of interrelated factors including variations of biophysical and human influences. As the iNDVI/RR ratio is thought to remain stable through time, such trends can be interpreted as a measure of possible degradation or improvement of the vegetation growth.

\section{Results and discussions}

\subsection{Rainfall}

A preliminary analysis of rainfall data indicates increasing rainfall in Burkina Faso during the studied period (figure 2). Overall, $91.4 \%$ of May to October rainfall recorded positive trends over the 1982-1999 period (not shown). In detail, 37.5\% and $23.4 \%$ of the stations showed a strong and weak positive trend, respectively. Stability characterised $36.7 \%$ of the analysed stations, while only $2.4 \%$ recorded a weak negative trend.

Such results were expected, especially when considering that the drought period culminated in the early 1980s (Nicholson 1985, L'Hôte et al. 2002); that is, the beginning of the analysed dataset. In addition, these results are in accordance with recent investigations on rainfall variations in the Sahel suggesting that the drought may have ended in the early 1990s (Ozer et al. 2003).

\section{2 iNDVI}

Over the 128 pixels analysed in Burkina Faso, $73.4 \%$ and $13.2 \%$ presented a strong and weak positive change in iNDVI, respectively, while it remained stable in $13.3 \%$ of cases (not shown).

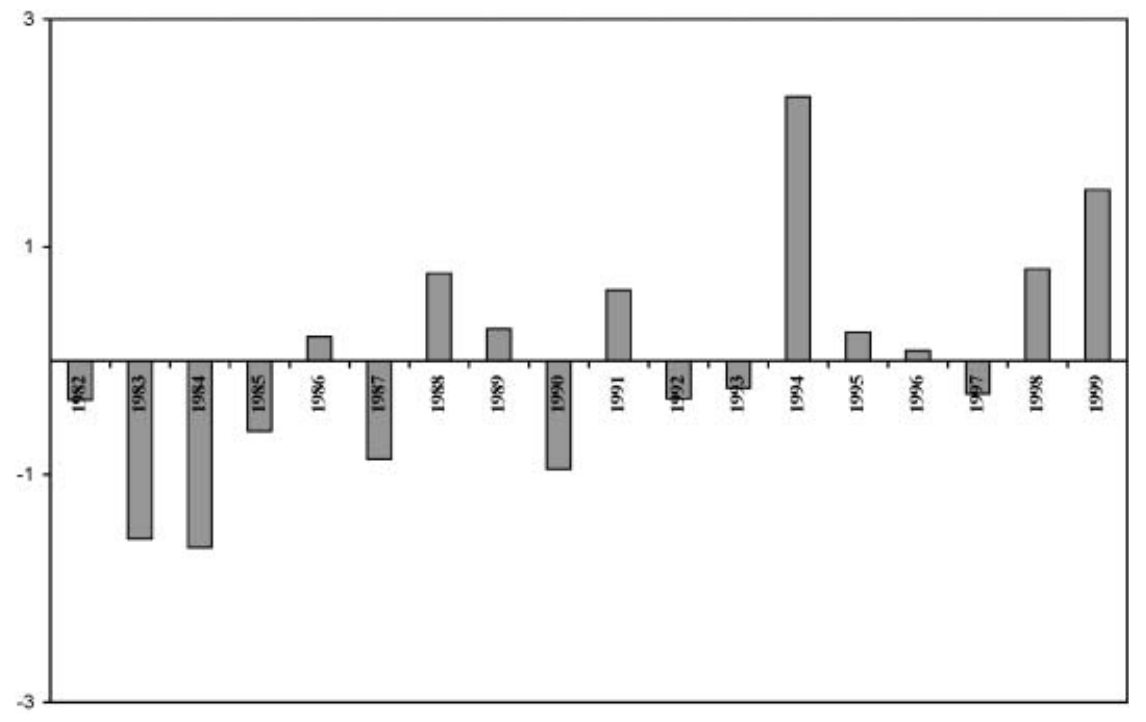

Figure 2. Standardised rainfall deviation from the 21-year mean for 128 stations in Burkina Faso. 
Again, these results are similar to those of Eklundh and Olsson (2003) who observed a strong increase in seasonal NDVI in the Sahel since 1982 interpreted as vegetation recovery from the drought periods of the 1980s. Other detailed studies in Burkina Faso showed that after a long period of strong land degradation (Chamard and Courel 1979, Lindqvist and Tengberg 1994), vegetation recovery was observed during the 1990s (Rasmussen et al. 2001, Pearce 2002).

Now, an unanswered question remains: Is this vegetation recovery fully resilient with increasing rainfall? For this, setting up a relationship between rainfall and biomass (iNDVI) and performing trend analysis on the iNDVI/RR ratio could give the answer to that question.

\subsection{Rainfall-iNDVI relationship}

Separate linear regression models between biomass (iNDVI) and rainfall were computed for all sites surveyed pooled into bioclimatic areas. For each year, the average values of iNDVI and rainfall during the growing season have been calculated and reveal that the rainfall-iNDVI relationship is relatively strong for all years $\left(R^{2}=0.82\right.$ on average). This result is in accordance with a previous study, which reported a similar relationship between rainfall and NDVI $\left(R^{2}=0.85\right.$; Malo and Nicholson, 1990). However, this previous study dealt with a larger geographic area, characterized by a greater range of mean annual precipitation (from 10 to $1000 \mathrm{~mm}$ ) and it covered only four years with exceptionally low precipitation. Integrating rainfall during the growing season annually, as we have done, may also be causing the relatively high correlation between rainfall and biomass. Contrary to our results, Prince et al. (1998) reported results with a $R^{2}=0.52$ between rainfall and net primary production observed for 214 Sahelian sites over nine years.

Thus, even though rainfall controls a large part of the spatial and temporal variation in biomass at the regional scale, it is clear that, at the local scale, there is considerable variation in the response of vegetation to rainfall. As suggested by Diouf and Lambin (2000), this could depend on soil type, inter-annual variations in rain-use efficiency, presence of plant seeds, vegetation communities and floristic composition, land-use practices, and seasonal distribution of rainfall. For the purpose of the present paper, we do not deepen these aspects.

\section{4 iNDVIIRR ratio}

Trend classes for change in the iNDVI/RR ratio are summarized in table 1 and the spatial repartition of the concerned stations is mapped in figure 3. Overall, a negative slope is recorded in $84.4 \%$ of the 128 analysed stations, while the remaining stations $(15.6 \%)$ are characterised by a positive trend. Detailed analysis shows that, for all considered stations, most areas (57.8\%) remained stable during the 1982-1999 period. However, $16.4 \%$ and $23.4 \%$ presented a strong and weak negative change, respectively. Only, $2.4 \%$ showed a weak positive trend. About $40 \%$ of the analysed stations have therefore experienced decreasing trends in the iNDVI/RR ratio that may reflect possible degradation of the vegetation growth, and therefore ongoing desertification processes. The geographical distribution of downward weak to strong trends is fuzzy and may indicate localised land degradation processes in some places while few others may experience improved land management.

Differences in changes are highlighted when considering phytogeographic areas of Burkina Faso (figure 4). In the Sahelian belt $(<500 \mathrm{~mm}$ in annual rainfall), $75 \%$ of 
Table 1. Trend of the iNDVI/RR ratio in Burkina Faso (1982-1999).

\begin{tabular}{|c|c|c|c|c|c|c|c|c|c|c|c|c|c|}
\hline \multirow[b]{2}{*}{$\begin{array}{l}\text { Phytoclimatic } \\
\text { zones (isohyets } \\
\text { boundary) }\end{array}$} & \multirow[b]{2}{*}{$\begin{array}{c}\text { Number } \\
\text { of } \\
\text { studied } \\
\text { stations }\end{array}$} & \multicolumn{4}{|c|}{ Slopes } & \multicolumn{8}{|c|}{ Trends significance } \\
\hline & & $\begin{array}{l}\text { Negative } \\
\text { slope }\end{array}$ & $\%$ & $\begin{array}{l}\text { Positive } \\
\text { slope }\end{array}$ & $\%$ & $\begin{array}{c}\text { Strong } \\
\text { negative } \\
\text { change } \\
(p<0.1)\end{array}$ & $\%$ & $\begin{array}{c}\text { Weak } \\
\text { negative } \\
\text { change } \\
(0.1<p \\
<0.3)\end{array}$ & $\%$ & $\begin{array}{c}\text { Stable } \\
(p>0.3)\end{array}$ & $\%$ & $\begin{array}{c}\text { Weak } \\
\text { positive } \\
\text { change } \\
(0.1<p \\
<0.3)\end{array}$ & $\%$ \\
\hline$P<500 \mathrm{~mm}$ & 12 & 10 & 83.3 & 2 & 16.7 & 2 & 16.7 & 1 & 8.3 & 9 & 75.0 & 0 & 0 \\
\hline $500<P<750 \mathrm{~mm}$ & 54 & 43 & 79.6 & 11 & 20.4 & 15 & 27.8 & 11 & 20.4 & 25 & 46.3 & 3 & 5.5 \\
\hline $750<P<1000 \mathrm{~mm}$ & 45 & 42 & 93.3 & 3 & 6.7 & 4 & 8.9 & 14 & 31.1 & 27 & 60.0 & 0 & 0 \\
\hline
\end{tabular}




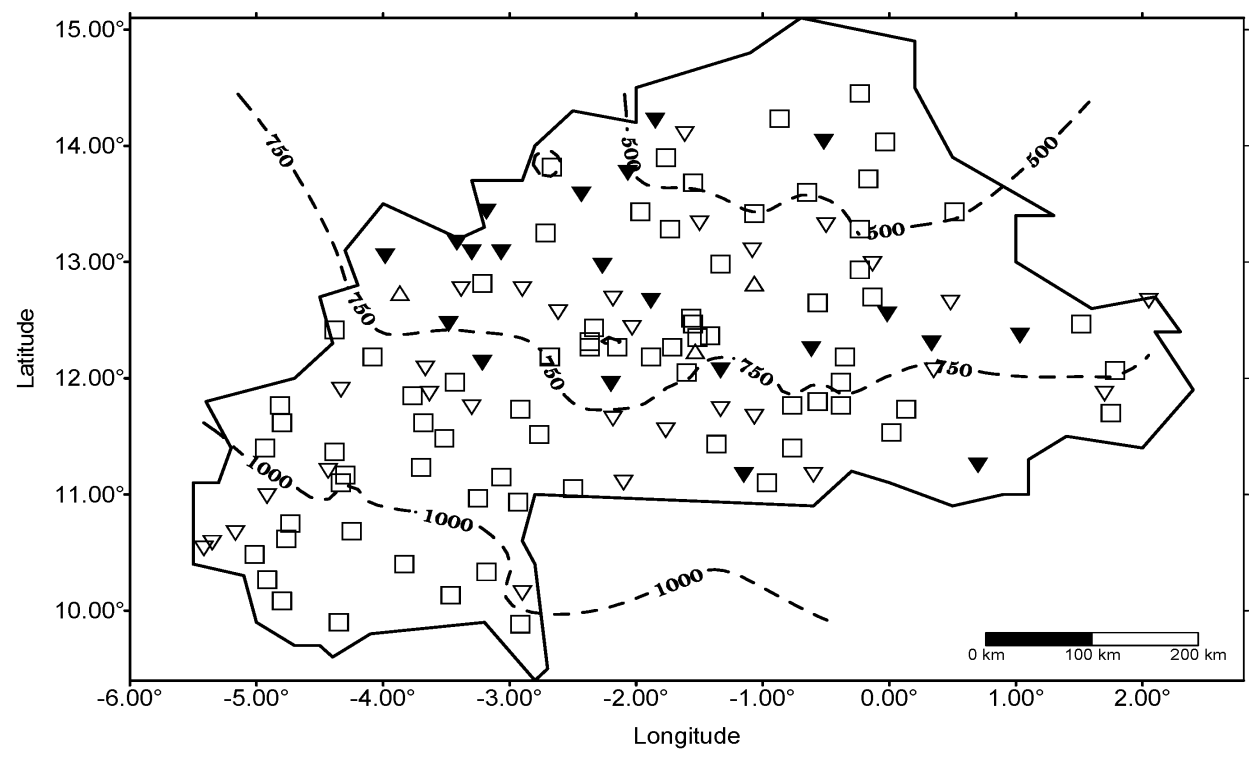

Figure 3. Trends in the iNDVI/RR ratio during the growing season (May-October) for 128 stations in Burkina Faso (1982-1999). $\nabla$, strong negative change; $\nabla$, weak negative change; $\square$, stable; $\triangle$, weak positive change.

the stations presented a relative stability, $8.3 \%$ showed a weak negative change and $16.7 \%$ strongly decreased. The Sahelo-Sudanese zone in the central north seems to have been the most affected by land degradation as vegetation resilience to rainfall is the lowest among all phytogeographic areas of Burkina Faso. Yet, less than a half $(46.3 \%)$ of the 54 stations included in this region show a stable iNDVI/RR ratio, while $27.8 \%$ experienced a strong negative trend and $20.4 \%$ a weak negative change. However, it is worth mentioning that this region includes the only stations of Burkina Faso that display a weak positive change (5.5\%). In the Sudanese zone in

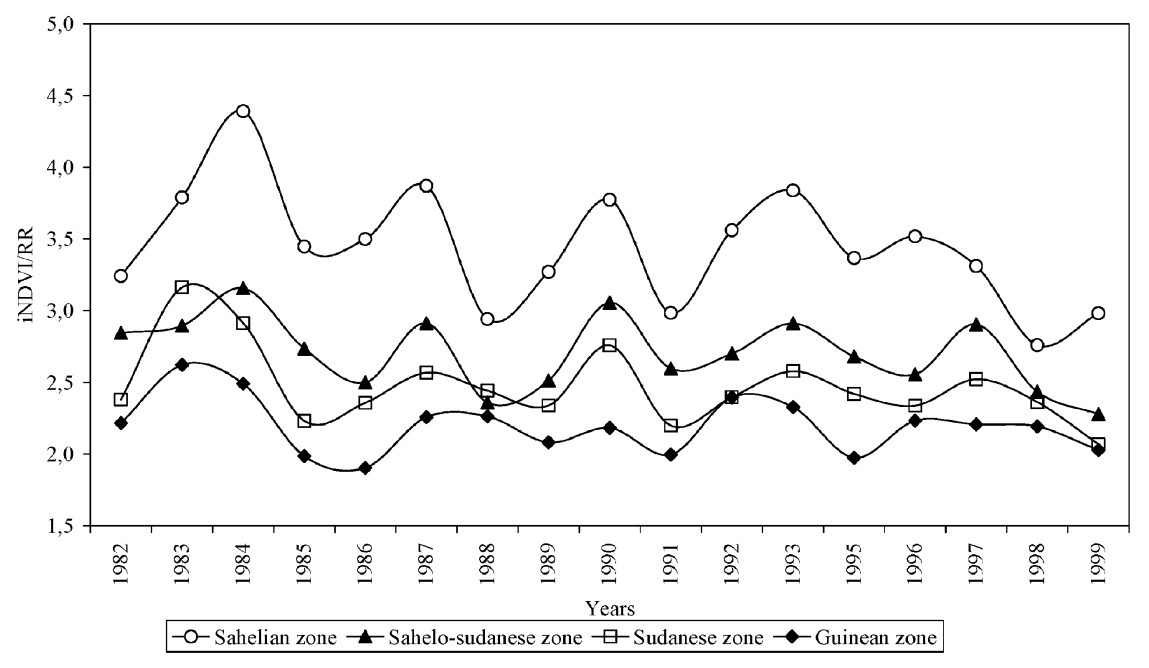

Figure 4. Annual ratio of integrated NDVI to rainfall during growing season (MayOctober). The sites were pooled with 1980-2000 rainfall means. 
the central south $(750-1000 \mathrm{~mm}), 60 \%$ of the stations appeared to be stable, while $8.9 \%$ and $31.1 \%$ suffered from a strong and weak negative change, respectively. In a wetter environment, the Sudano-Guinean zone was mostly stable (76.5\%) and $23.5 \%$ of the considered stations were subjected to a weak negative change. However, the results obtained in this southern region should be looked at with care as previous studies mentioned that the relationship between NDVI and rainfall tends to weaken when annual rainfall is higher than $1000 \mathrm{~mm}$. As primary production remains relatively constant, water being not a major limiting factor (Nicholson et al. 1990, Davenport and Nicholson 1993).

Such contrasting evolutions along the bioclimatic gradients of Burkina Faso are in accordance with recent findings of Hiernaux and Turner (2002). These authors stated that risks of environmental degradations are moderate and mainly climatedriven in pastoral systems at the drier edge, while they are serious and mainly management-driven in the crop-livestock systems of the Sahelo-Sudanese zone. Our results indeed show that $75 \%$ of the stations remained stable in the northern part of the country, while about half of the analysed stations suffered from strong or weak negative changes in the Sahelo-Sudanese zone in the central north. As a matter of fact, Henry and colleagues (2003) showed that migration flows from the northern ecologically marginal Provinces of Burkina Faso to the Sahelo-Sudanese zone were partly explained by unfavourable environmental variables such as high rainfall variability, land degradation, and land availability at the origin, and favourable conditions at the destination for these variables. For this reason, there is currently less pressure in the northern part of Burkina Faso as people migrated because of the drought while migrations are likely to contribute to negative environmental changes at the destination (Lambin et al. 2001).

Recent claims that the Sahel is greening since the 1990s because of improved land management (Mazzucato and Niemeijer 2000, Rasmussen et al. 2001, Niemeijer and Mazzucato 2002, Pearce 2002, Eklundh and Olsson 2003) may be only partly true. As an example, Mazzucato and Niemeijer (2000) closely studied two small areas (Bilanga and Fada-N'Gourma) in Eastern Burkina Faso and suggested that these areas showed no evidence of land degradation as crop yields increased. Our results on these two stations indeed show that if the iNDVI presented positive slopes, the iNDVI/RR ratio experienced a strong negative change in Bilanga and a weak negative change in Fada-N'Gourma, suggesting that the rain-use efficiency of the vegetation has been declining over the last two decades (figures 5 and 6). In northern Burkina Faso (Gorom-Gorom), Rasmussen et al. (2001) suggested that desertification was in reverse, demonstrating that vegetation was reclaiming fossil dunes revitalized during the droughts of the 1970s and 1980s. Our results at this station (Figure 7) suggest that the iNDVI strongly increased and that the iNDVI/RR ratio remained stable during the 1980s and 1990s. In this specific case, it can be accepted that the vegetation is resilient with the rainfall increase observed during the last decade.

As mentioned above, many biophysical and human influences may interfere in the evolution of the iNDVI/RR ratio. Increasing use of fertilisers, better water resources management and land rehabilitation measures have improved over the years. But despite such positive technical evolutions, only three stations out of 128 recorded a weak positive change the iNDVI/RR ratio over the 1982-1999 period. Another interference in the evolution of the $\mathrm{iNDVI} / \mathrm{RR}$ ratio may be attributed to climate change due to the ongoing build-up of greenhouse gases. In many regions of the 


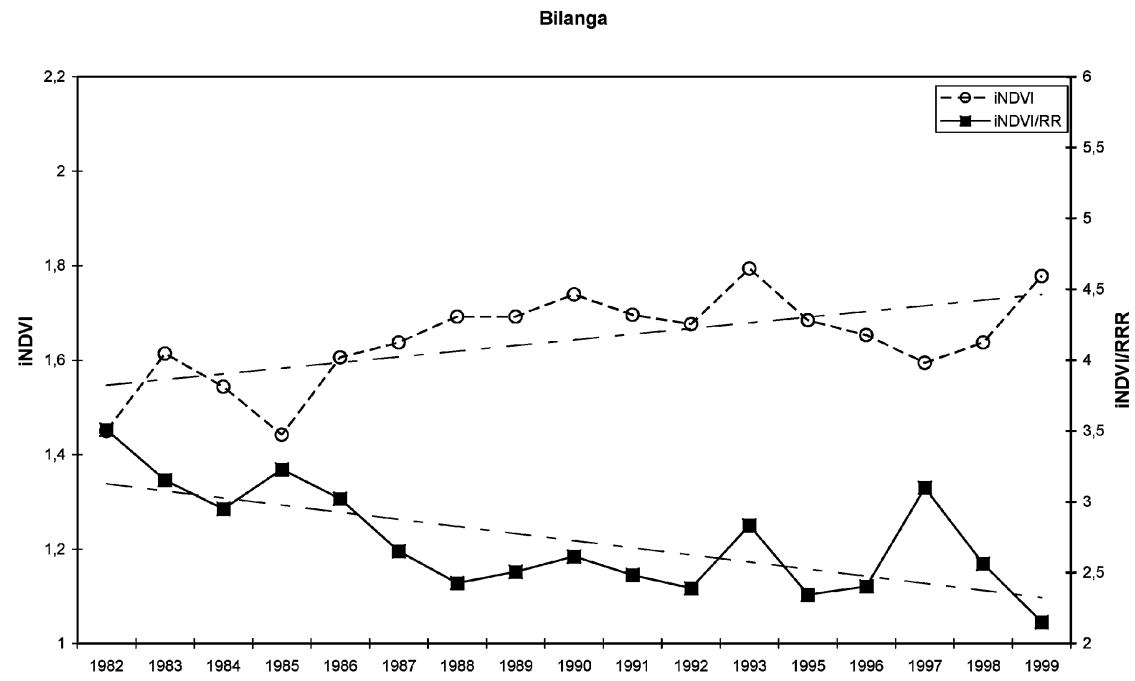

Figure 5. Inter-annual variability of integrated NDVI and iNDVI/RR ratio as a proxy of rain use efficiency at Bilanga site (Eastern Burkina Faso).

world, extreme precipitation events have significantly increased during the last decades (Houghton et al. 2001, Kunkel 2003, Roy and Balling 2004). Although no research on this topic is available in West Africa, a large increase in floods due to excess precipitation in short time periods has been observed lately that may suggest an increasing tendency in extreme precipitation events (Sene and Ozer 2002). If this trend was confirmed, then the iNDVI/RR ratio may be negatively affected as extreme daily precipitation can not be fully used by vegetation and can further cause erosion and soil crusting.

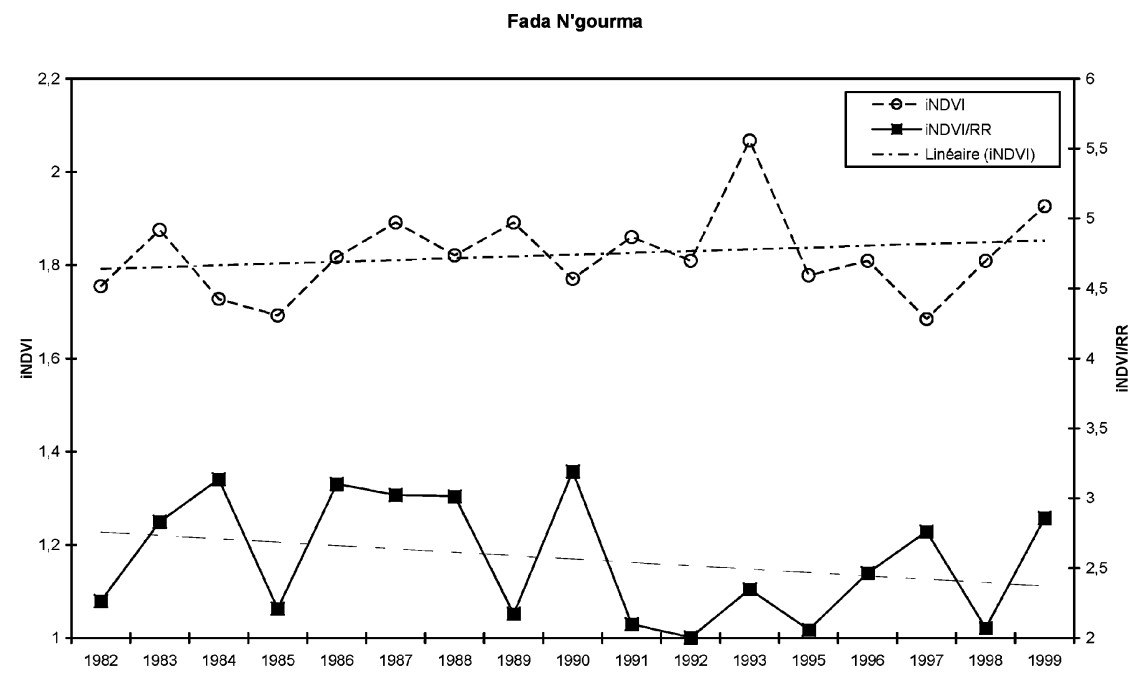

Figure 6. Inter-annual variability of integrated NDVI and iNDVI/RR ratio as a proxy of rain use efficiency at Fada N'gourma site (Eastern Burkina Faso). 


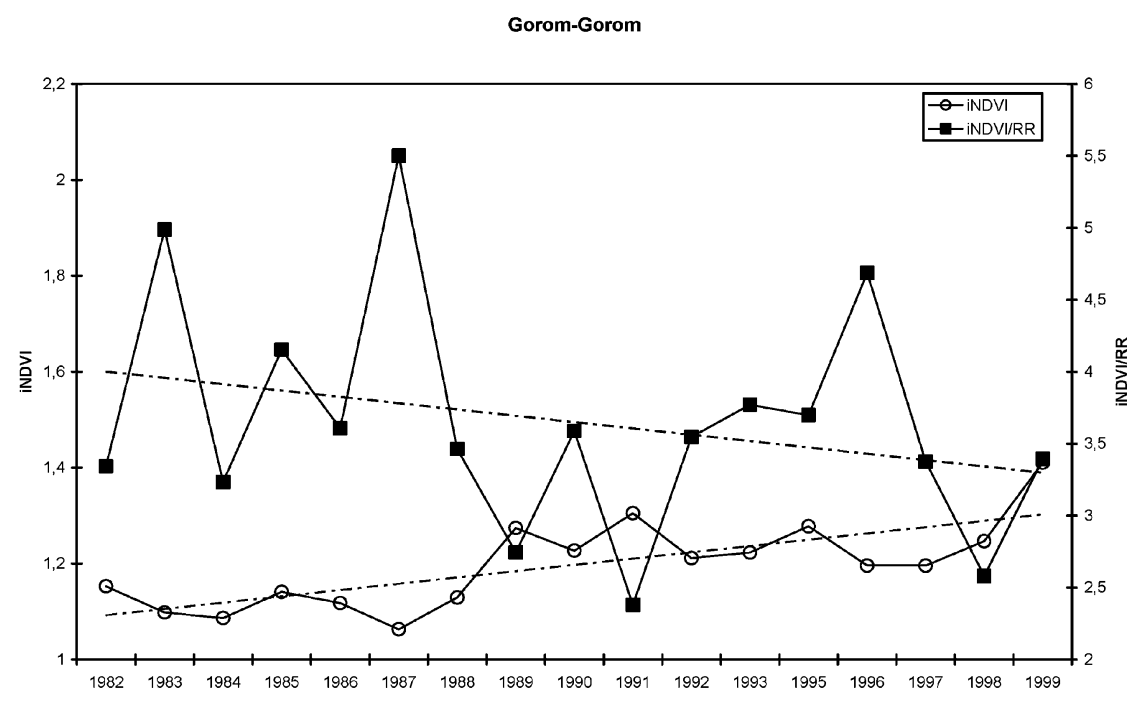

Figure 7. Inter-annual variability of integrated NDVI and iNDVI/RR ratio as a proxy of rain use efficiency at Gorom-gorom site (Northern Burkina Faso).

\section{Conclusions}

Based on observations of increased crop yields and/or NDVI, recent studies have stated that desertification in the African Sahel was in reverse. However, using trends in the iNDVI/RR ratio, our results suggest that about $40 \%$ of the analysed stations of Burkina Faso may have experienced ongoing desertification processes during 1982-1999. Our findings present an environmental situation that is probably gloomier than recent papers stated, although we are far from the concept of irreversible land degradation that was so fashionable until recently.

Such approach could be used to monitor land degradation in other arid and semiarid and sub-humid regions of the world $(<750 \mathrm{~mm})$. However, the use of iNDVI/ $\mathrm{RR}$ as a desertification indicator in wetter environment may not be valid because primary production remains relatively constant, and water is not a major limiting factor any more.

Otherwise, longer time series could be developed by combining low resolution satellite data of different sensors, such as NOAA-AVHRR for the 1982-1999 period and SPOT-VEGETATION from 2000 onwards. Finally, obtained results could be a starting point for the identification of hot-spots areas to determine where to take actions to combat desertification at national scale as recommended in the United Nations Convention to Combat Desertification.

\section{Acknowledgements}

The authors wish to thank the two anonymous referees for the in-depth review of the paper and for the helpful comments. The present research has been developed with the financial support of the Kingdom of Belgium through the Commission Universitaire pour le Développement (CUD), which funded the doctoral training of the first author. 


\section{References}

Amani, A. and Lebel, T., 1997, Lagrangian kriging for the estimation of Sahelian rainfall at small time steps. Journal of Hydrology, 192, pp. 125-157.

Berger, A.R., 1996, Introduction to geoindicator checklist. In Geoindicators - Assessing rapid environmental changes in earth systems, A.R. Berger and W.J. Iams (Eds), pp. 383-394 (Rotterdam: A.A. Balkema).

Chamard, P.C. and Courel, M.F., 1979, Contribution à l'étude du Sahel voltaïque. Causes et conséquences de la dégradation du couvert végétal des dunes. Secteur de MénégouBidi. Travaux de l'Institut de Géographie de Reims, 39-40, pp. 75-90.

Chappell, A., Seaquist, J.W. and Eklundh, L., 2001, Improving the estimation of noise from NOAA AVHRR NDVI for Africa using geostatistics. International Journal of Remote Sensing, 22, pp. 1067-1080.

Dai, A., Trenberth, K.E. and Karl, T.R., 1998, Global variations in droughts and wet spells: 1900-1995. Geophysical Research Letters, 25, pp. 3367-3370.

Davenport, M.L. and Nicholson, S.E., 1993, On the relation between rainfall and Normalized Difference Vegetation Index for diverse vegetation types in East Africa. International Journal of Remote Sensing, 12, pp. 2369-2389.

Diallo, O., Diouf, A., Hana, N.P., Ndiay, A. and Prevost, Y., 1991, AVHRR monitoring of primary production in Senegal, West Africa. International Journal of Remote Sensing, 12, pp. 1259-1279.

Diouf, A. and Lambin, E.F., 2001, Monitoring land-cover changes in semi-arid regions: remote sensing data and field observations in the Ferlo, Senegal. Journal of Arid Environments, $\mathbf{4 8}$, pp. 129-148.

EkLundH, L. and Olsson, L., 2003, Vegetation index trends for the African Sahel 1982-1999. Geophysical Research Letters, 30, 10.1029/2002GL016772.

FAO 2001, Global Forest Resources assessment 2000, FAO Forestry Paper 140 (Rome: FAO).

FAO 2004, FAOSTATS - Statistics Database 2004. Available online at: http://apps.fao.org/ (accessed 2 February 2005).

Foody, G.M., 2003, Geographical weighting as a further refinement to regression modelling: an example focused on the NDVI-rainfall relationship. Remote Sensing of Environment, 88, pp. 283-293.

Glenn, E., Stafford Smith, M. and Squires, V., 1998, On our failure to control desertification: implications for global change issues, and a research agenda for the future. Environmental Science and Policy, 1, pp. 71-78.

Golden Software 1994, Surfer, Surface Mapping System (Colorado: Golden Software, online information). Available online at: http://www.goldensoftware.com/products/ surfer/surfer.shtml.

Hellden, U., 1991, Desertification-Time for an assessment? Ambio, 20, pp. 372-383.

Henri, S., Boyle, P. and Lambin, E., 2003, Modelling inter-provincial migration in Burkina Faso, West Africa: the role of socio-demographic and environment factors. Applied Geography, 23, pp. 115-136.

Hess, T., Stephens, W. and Thomas, G., 1996, Modelling NDVI from decadal rainfall data in the North East arid zone of Nigeria. Journal of Environmental Management, 48, pp. 249-261.

Hiernaux, P. and Turner, M.D., 2002, The influence of farmer and pastoralist management practices on desertification processes in the Sahel. In Global Desertification: Do Humans Cause Deserts?, J.F. Reynolds and D.M. Stafford Smith (Eds), pp. 135-148 (Dalhem: Dalhem University Press).

Houghton, J.T., Ding, Y., Griggs, D.J., Noguer, M., van der Linden P.J., Dai, X., Maskell, K. and Johnson, C.A., 2001, Climate Change 2001: The Scientific Basis (New York: Cambridge University Press).

James, M.E. and Kalluri, S.N.V., 1994, The Pathfinder AVHRR land data set: an improved coarse resolution data set for terrestrial monitoring. International Journal of Remote Sensing, 15, pp. 3347-3364. 
Justice, C.O., 1986, Monitoring the grasslands of semi-arid Africa using NOAA-AVHRR data. International Journal of Remote Sensing, 7, pp. 1383-1622.

Kunkel, K., 2003, North American trends in extreme precipitation. Natural Hazards, 29, pp. 291-305.

L'Hôte, T., Mahé, G., Somé, B. and Triboulet, J.P., 2002, Analysis of a Sahelian annual rainfall index from 1896 to 2000; the drought continues. Hydrological Sciences Journal, 47, pp. 563-572.

Lambin, E.F., Turner II B.L., Geist, H., Agbola, S., Angelsen, A., Bruce, J.W., Coomes, O., Dirzo, R., Fischer, G. and Folke, C., et al. 2001, The causes of landuse and land-cover change: moving beyond the myths. Global Environmental Change, 11, pp. 261-269.

LAmprey, H., 1975, Report on the Desert Encroachment Reconnaissance in Northern Sudan (Khartoum: National Council for Research, Ministry of Agriculture of Sudan).

Le Houérou, H.-N., 1984, Rain-use efficiency: a unifying concept in arid land ecology. Journal of Arid Environments, 7, pp. 1-35.

Lindqvist, S. and Tengberg, A., 1994, New evidence of desertification from case studies in Northern Burkina Faso. Desertification Control Bulletin, 25, pp. 54-60.

Mabbutt, J.A., 1986, Desertification indicators. Climatic Change, 9, pp. 113-122.

Mainguet, M., 1991, Desertification: Natural Background and Human Mismanagement (Berlin: Springer-Verlag).

Malo, A.R. and Nicholson, S.E., 1990, A study of rainfall and vegetation dynamics in the African Sahel using normalised difference vegetation index. Journal of Arid Environments, 19, pp. 1-24.

Mazzucato, V. and Niemeijer, D., 2000, The cultural economy of soil and water conservation: market principles and social networks in Eastern Burkina Faso. Development and Change, 31, pp. 831-855.

Milich, L. and WeISS, E., 2000a, GAC NDVI interannual coefficient of variation (CoV) images: ground truth sampling of the Sahel along north-south transects. International Journal of Remote Sensing, 21, pp. 235-260.

Milich, L. and Weiss, E., 2000b, GAC NDVI images: relationship to rainfall and potential evaporation in the grazing lands of the Gourma (northern Sahel) and in the croplands of the Niger-Nigeria border (southern Sahel). International Journal of Remote Sensing, 21, pp. 261-280.

Mouat, D., Lancaster, J., Wade, T., Wickham, J., Fox, C., Kepner, W. and Ball, T., 1997, Desertification evaluated using an integrated environmental assessment model. Environment Monitoring and Assessment, 48, pp. 139-156.

Nicholson, S.E., 1985, Sub-Saharan rainfall 1981-1984. Journal of Climate and Applied Meteorology, 24, pp. 1388-1391.

Nicholson, S.E., 1998, Interannual and interdecadal variability of rainfall over the African continent during the last two centuries. IAHS Publication, 252, pp. 107-116.

Nicholson, S.E., Davenport, M.L. and Malo, A.R., 1990, A comparison of the vegetation response to rainfall in the Sahel and East Africa, using normalized difference vegetation index from NOAA AVHRR. Climatic Change, 17, pp. 209-241.

Nicholson, S.E., Tucker, C.J. and BA, M.B., 1998, Desertification, drought, and surface vegetation: an example from the West African Sahel. Bulletin of the American Meteorological Society, 79, pp. 815-829.

Niemeijer, D. and Mazzucato, V., 2002, Soil degradation in the West African Sahel. How serious is it? Environment, 44, pp. 20-31.

Ozer, P., 2000, Les lithométéores en région sahélienne: un indicateur climatique de la désertification. GEO-ECO-TROP, 24, pp. 1-317.

Ozer, P., Erpicum, M., Demaree, G. and Vandiepenbeeck, M., 2003, The Sahelian drought may have ended during the 1990s. Hydrological Sciences Journal, 48, pp. 489-492. 
Pearce, F., 2002, Africans go back to the land as plants reclaim the desert. New Scientist, 175, pp. 4-5.

Prince, S.D., 2002, Spatial and temporal scales for detection of desertification. In Global Desertification: Do Humans Cause Deserts?, J.F. Reynolds and D.M. Stafford Smith (Eds), pp. 23-40 (Dalhem: Dalhem University Press).

PRINCE, S.D., 1991, Satellite remote sensing of primary production: Comparison of results for Sahelian grasslands 1981-1988. International Journal of Remote Sensing, 12, pp. 1301-1311.

PrinCE, S.D. and GowARD, S.N., 1996, Evaluation of the NOAA/NASA Pathfinder AVHRR Land Data Set for global primary production modelling. International Journal of Remote Sensing, 17, pp. 217-221.

Prince, S.D. and Justice, C.O., 1991, Coarse resolution remote sensing in the Sahelian environment. International Journal of Remote Sensing, 12, pp. 1133-1421.

Prince, S.D., Brown de Colstoun, E. and Kravitz, L.L., 1998, Increased rain-use efficiencies indicate no extensive Sahelian desertification. Global Change Biology, 4, pp. 359-374.

Rasmussen, K., Fog, B. and Madsen, J.E., 2001, Desertification in reverse? Observations from northern Burkina Faso. Global Environmental Change, 11, pp. 271-282.

Rasmussen, M.S., 1998, Developing simple, operational, consistent NDVI-vegetation models by applying environmental and climatic information: Part I. Assessment of net primary production. International Journal of Remote Sensing, 19, pp. 97-117.

Roy, S.S. and BAlling, R.C., 2004, Trends in extreme daily precipitation indices in India. International Journal of Climatology, 24, pp. 457-466.

SENE, S. and OzER, P., 2002, Evolution pluviométrique et relation inondations-événements pluvieux au Sénégal. Bulletin de la Société Géographique de Liège, 42, pp. 27-33.

Symeonakis, E. and DraKe, N., 2004, Monitoring desertification and land degradation over sub-Saharan Africa. International Journal of Remote Sensing, 25, pp. 573-592.

Tanaka, S., Sugimura, T., Harada, T. and Tanaka, M., 1994, Pinatubo volcanic dust diffusion into the stratosphere seen from space. Advances in Space Research, 14, pp. $245-254$.

Tномаs, D.S.G., 1993, Sandstorm in a teacup? Understanding desertification. The Geographical Journal, 159, pp. 318-331.

Thomas, D.S.G. and Middleton, N.J., 1994, Desertification: Exploding the Myth (Chichester: Wiley).

Tottrup, C. and Rasmussen, M.S., 2004, Mapping long-term changes in savannah crop productivity in Senegal through trend analysis of time series of remote sensing data. Agriculture, Ecosystems and Environment, 103, pp. 545-560.

Tucker, C.J., Degne, H.E. and Newcomb, W.W., 1991, Expansion and contraction of the Sahara desert from 1980 to 1990. Science, 253, pp. 299-301.

Tucker, C.J., Newcomb, W.W. and Degne, H.C., 1994, AVHRR data sets for determination of the desert spatial expent. International Journal of Remote Sensing, 15, pp. 3547-3566.

Tucker, C.J. and Nicholson, S.E., 1999, Variations in size of the Sahara Desert from 1980 to 1997 . Ambio, 28, pp. 587-591.

UN 1994, United Nations convention to combat desertification in countries experiencing serious drought and/or desertification, particularly in Africa. Available online at: http://www.unccd.int/convention/text/pdf/conv-eng.pdf (accessed 2 February 2005).

UNDP 2004, Human Development Report 2004 (New York: UNDP).

Verstraete, M.M., 1986, Defining desertification: a review. Climatic Change, 9, pp. 5-18.

WiCKENS, G.E., 1997, Has the Sahel a future? Journal of Arid Environments, 37, pp. 649-663.

World BANK 2003, World Development Report 2003: Sustainable Development in a Dynamic World: Transforming Institutions, Growth, and Quality of Life (New Delhi: Oxford University Press). 